\title{
REVIEW
}

\section{Prophylactic Modulation of Methane and Nitrous Oxide Emitted from Ruminants Livestock for Sustainable Animal Agriculture}

\author{
J. Takahashi \\ Graduate School of Animal Science, Obihiro University of Agriculture and Veterinary Medicine \\ Obihiro 080-8555, Japan, \\ College of Environmental Science and Engineering, Tongji University \\ Shanghai 200092, China \\ Department of Nutrition and Feed Technology, Faculty of Animal Science, Bogor Agricultural University \\ Kampus IPB Darmaga, Bogor 16680, Indonesia \\ (Received 19-11-2014; Reviewed 21-11-2014; Accepted 28-11-2014)
}

\begin{abstract}
Major greenhouse gases (GHG) attributed to animal agriculture sector are methane $\left(\mathrm{CH}_{4}\right)$ and nitrous oxide $\left(\mathrm{N}_{2} \mathrm{O}\right)$, either generated from enteric fermentation or manure. The abatement mechanism of rumen $\mathrm{CH}_{4}$ emission may be divided to direct and indirect suppression to methanogens in the rumen. The most significant strategy to mitigate ruminal $\mathrm{CH}_{4}$ emission in indirect manner is to promote alternative metabolic pathway to dispose of the reducing power, competing with methanogenesis for $\mathrm{H}_{2}$ uptake. This includes prebiotics and probiotics (mostly propionate enhancers) which consume metabolic hydrogen $\left(\mathrm{H}_{2}\right)$ compete with methanogens and abate rumen methanogenesis in indirect manner. With regard to mitigate GHG emissions from manure, such waste has been proposed as a renewable energy and nitrogen sources through biogas plant. Furthermore, in advanced new biogas system, the ammonia stripping from digested slurry of livestock manure in biogas plant has been examined to apply to nitrogen recycling-options mitigating $\mathrm{N}_{2} \mathrm{O}$ emission. These options are: (1) ammonolysis on fiber-rich feedstuffs, (2) saccharification of the $\mathrm{NH}_{3}$ treated cellulose biomass to produce bio-ethanol, and (3) reformed hydrogen into $\mathrm{NH}_{3}$ fuel cell to generate electricity with proton exchange membrane fuel cell (PEM).
\end{abstract}

Key words: rumen methane, nitrous oxide, probiotics, prebiotics, ammonia stripping

\section{ABSTRAK}

Gas rumah kaca (GRK) yang terkait dengan sektor peternakan adalah metana $\left(\mathrm{CH}_{4}\right)$ dan dinitrogen oksida $\left(\mathrm{N}_{2} \mathrm{O}\right)$, baik yang dihasilkan melalui proses fermentasi enterik maupun manur. Mekanisme mitigasi emisi metana dapat dibagi menjadi penghambatan secara langsung dan tidak langsung terhadap populasi metanogen di rumen. Strategi utama menurunkan emisi metana dari rumen secara tidak langsung adalah dengan cara menyediakan jalur alternatif penggunaan $\mathrm{H}_{2}$ selain dari metanogenesis. Strategi ini diantaranya adalah melalui pemanfaatan prebiotik dan probiotik (umumnya peningkat propionat) yang juga mengkonsumsi hidrogen metabolik sehingga berkompetisi dengan metanogen. Adapun upaya mengurangi GRK dari manur adalah melalui instalasi biogas. Dalam sistem biogas yang canggih, emisi $\mathrm{N}_{2} \mathrm{O}$ dari manur didaur ulang menjadi amonia $\left(\mathrm{NH}_{3}\right)$. Amonia yang dihasilkan kemudian digunakan untuk: (1) amoniasi pakan berserat tinggi, (2) sakarifikasi dari biomassa tinggi selulosa yang telah diamoniasi untuk menghasilkan bioetanol, dan (3) reformasi hidrogen menjadi sel bahan bakar berbasis $\mathrm{NH}_{3}$ untuk menghasilkan energi listrik.

Kata kunci: metana, dinitrogen oksida, probiotik, prebiotik, amonia

*Corresponding author:

E-mail: junichi@obihiro.ac.jp 


\section{INTRODUCTION}

The mitigation of anthropogenic four GHG, carbon dioxide $\left(\mathrm{CO}_{2}\right)$, methane $\left(\mathrm{CH}_{4}\right)$, nitrous oxide $\left(\mathrm{N}_{2} \mathrm{O}\right)$ and sulphur hexafluoride ( $\left.\mathrm{SF}_{6}\right)$ and two groups of $\mathrm{GHG}$, hydrofluorocarbons (HFCs) and perfluorocarbons (PFCs) have been established as legally binding commitments in The Kyoto Protocol (IPCC, 1996). Important GHG attributed to animal agriculture are $\mathrm{CH}_{4}$ and $\mathrm{N}_{2} \mathrm{O}$. Rumen fermentation of ruminant livestock and anaerobic fermentation of agricultural organic waste including animal manures are major contributors of $\mathrm{CH}_{4}$ emission as anthropogenic sources (Moss, 1993).

To abate the GHG, the development of mitigation methods of rumen $\mathrm{CH}_{4}$ is the most significant issue in the world ruminant livestock production (Van Nevel \& Demeyer, 1996). $\mathrm{CH}_{4}$ emitted from ruminants is generated in the rumen by hydrogenotrophic methanogens that utilize hydrogen to reduce $\mathrm{CO}_{2}$, and is a significant electron sink in the rumen ecosystem (Klieve \& Hegarty, 1999). $\mathrm{CH}_{4}$ contains $892.6 \mathrm{~kJ}$ combustible energy per molecule at $25{ }^{\circ} \mathrm{C}$ and $1013 \mathrm{hPa}$, while not contributing to the total supply of metabolic energy to ruminants (Takahashi et al., 1997). As reported by Leng (1991), $\mathrm{CH}_{4}$ production from ruminants in the developing countries may be high since the diets are often deficient in critical nutrients for efficient microbial growth in the rumen. So far, a number of inhibitors of methanogenesis have been developed to improve feed conversion efficiency of ruminant feeds claimed to be effective in suppressing methanogens or overall bacterial activities (Chalupa, 1984). Attempts to reduce methanogenesis by the supplementation of chemicals such as ionophores (monensin and lasalocid), have long been made (Chalupa, 1984; Hopgood \& Walker, 1967). However, these ionophores may depress fiber digestion and protozoal growths (Chen \& Wolin, 1979). In addition, some resistant bacteria will appear in the rumen from the results of long term use of the ionophores. Thus, development of manipulators to mitigate rumen methanogenesis must pay attention to secure safety for animals, their products and environment as alternatives of ionophores. Theoretically, methanogenesis can be reduced by either a decrease in the production of $\mathrm{H}_{2}$, the major substrates for $\mathrm{CH}_{4}$ formation or an increase in the utilization of $\mathrm{H}_{2}$ and formate by organisms other than methanogens (Figure 1). However, direct inhibition of $\mathrm{H}_{2}$-forming reactions may depress fermentation in microorganisms that produce $\mathrm{H}_{2}$, including main cellulolytic bacteria such as Ruminococcus albus and Ruminococcus flavefaciens (Belaich et al., 1990; Wolin, 1975). Therefore, a reduction in $\mathrm{H}_{2}$ production by the enhancement of reactions that accept electrons is desirable (Stewart \& Bryant, 1988).

The prompt increase of atmospheric $\mathrm{N}_{2} \mathrm{O}$ since last century is closely related to abrupt expansion of human and animal population after an innovation of HaberBosch process. Severe environmental pollutions were caused at the same time though the reactive nitrogen withdrawn from atmosphere as stable paired nitrogen brought about prosperous food production. To secure food production preventing environmental catalyses by global warming sustainable development of animal agriculture should be sought in not only developed but also developing countries as an alternative way. Inventories of emitters and their abatements are accurately assessed in both GHG. The key element of these recycling must be low-input for sustainable animal agriculture in developing countries. Carbon and nitrogen recycling in the agricultural biomass as renewable energy and nitrogen resources might contribute mitigation of $\mathrm{CH}_{4}$ and $\mathrm{N}_{2} \mathrm{O}$ (Takahashi et al., 2003; 2004; Takahashi, 2007; Takahashi \& Uemura, 2009).

The present paper deals with perspective on GHG control and possible uses of biomass towards sustainable animal agriculture.

\section{MITIGATION OF RUMEN METHANE EMISSION WITH PROBIOTICS AND PREBIOTICS}

In the rumen, metabolic $\mathrm{H}_{2}$ is produced during the anaerobic fermentation of glucose. This $\mathrm{H}_{2}$ can be used during the synthesis of volatile fatty acids and microbial organic matter. The excess $\mathrm{H}_{2}$ from $\mathrm{NADH}$ is eliminated primarily by the formation of $\mathrm{CH}_{4}$ by methanogens, which are microorganisms from the Archea group that are normally found in the rumen ecosystem (Baker, 1999). The stoichiometric balance of VFA, $\mathrm{CO}_{2}$ and $\mathrm{CH}_{4}$ indicates that acetate and butyrate promote $\mathrm{CH}_{4}$ production whereas propionate formation conserves $\mathrm{H}_{2}$, thereby reducing $\mathrm{CH}_{4}$ production (Wolin \& Miller, 1988). Therefore, a strategy to mitigate ruminal $\mathrm{CH}_{4}$ emission is to promote alternative metabolic pathway to dispose of the reducing power, competing with methanogenesis for $\mathrm{H}_{2}$ uptake. As assimilate nitrate reduction in the rumen

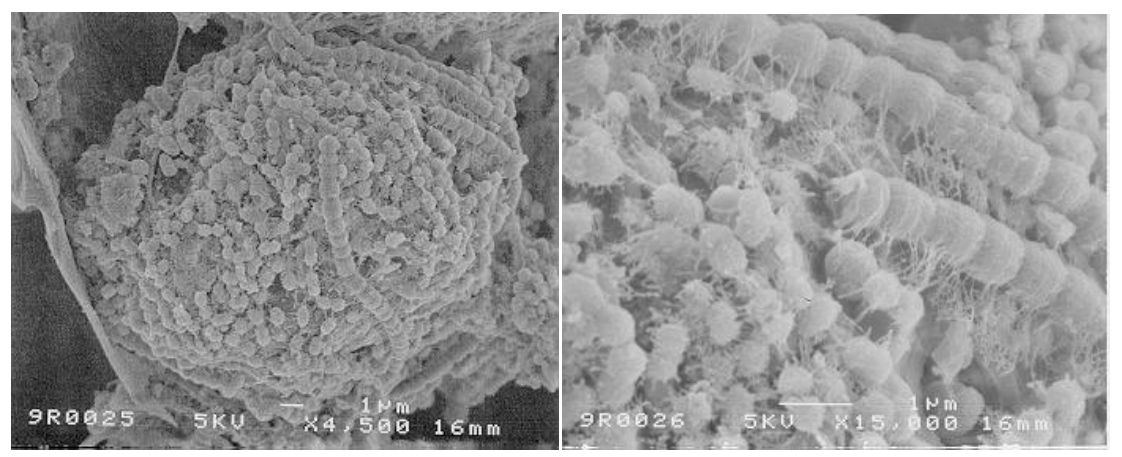

Figure1. Electric scanning microscopy of symbioses of methanogens on the surface of ciliate protozoa 
which shows strong redox potential is relatively higher affinity to $\mathrm{H}_{2}$ than hydrogenotrophic methanogenesis, the administration of nitrate remarkably suppressed ruminal methanogenesis (Takahashi \& Young, 1991; 1992).

Table 1 shows that the formation of toxic nitrite reduced from nitrate is successfully prevented by Lcysteine (Takahashi \& Young, 1991; 1992; Takahashi et al., 1989; 1998; 2000; 2002), the effective mitigation of ruminal $\mathrm{CH}_{4}$ emission is safely achieved by simultaneous administration of nitrate and L-cysteine without nitrate intoxication (Takahashi, 2001). Furthermore, Escherichia coli modified genetically was developed in an attempt to promote nitrite reduction abating ruminal methanogenesis (Sar et al., 2004a; 2005a; 2005b; 2005c) (Figure 2).

Figure 2 shows mitigating effect of Wild-type E. coli W3110 and the construction of E. coli nir-Ptac on rumen $\mathrm{CH}_{4}$ emission in sheep. $\mathrm{CH}_{4}$ emission was abated by the inoculation of wild-type E. coli W3110 or E. coli nir-Ptac, although the underlying mechanism has not been elucidated (Figure 3).
Rumen manipulation with ionophores such as monensin has been reported to abate rumen methanogenesis (Mwenya et al., 2005), However, there is an increasing interest in exploiting prebiotics and probiotics as natural feed additives to solve problems in animal

Table 1. The suppressing effect of L-cystein $\left(0.21 \mathrm{~g} \mathrm{~S} \mathrm{~kg}^{-0.75}\right.$ body weight) on nitrate -induced production of methaemoglobin (expressed as a percentage of total haemoglobin) and rumen methane production $\left(\mathrm{ml} \mathrm{mn}^{-1} \mathrm{~kg}^{-0.75}\right.$ body weight) in sheep $4 \mathrm{~h}$ after intra-ruminal administration of nitrate) $1.3 \mathrm{~g} \mathrm{NaNO}_{3} \mathrm{~kg}^{-0.75}$ body weight.

\begin{tabular}{lcccc}
\hline & \multicolumn{4}{c}{ Treatment } \\
\cline { 2 - 5 } & Control & $\mathrm{NO}_{3}$ & $\mathrm{NO}_{3}+\mathrm{CYS}$ & $\mathrm{CYS}$ \\
\hline Methaemoglobin (\%) & $0.5 \pm 0.4^{1, \mathrm{a}}$ & $16.1 \pm 3.0^{\mathrm{b}}$ & $3.9 \pm 2.4^{\mathrm{a}}$ & $0.5 \pm 0.4^{\mathrm{a}}$ \\
$\mathrm{CH}_{4}$ production & $2.1 \pm 0.2^{\mathrm{a}}$ & $0.3 \pm 0.0^{\mathrm{b}}$ & $0.7 \pm 0.2^{\mathrm{c}}$ & $1.2 \pm 0.2^{\mathrm{ab}}$ \\
$\left(\mathrm{mL} \mathrm{min}^{-1} \mathrm{~kg}^{-0.75} \mathrm{BW}\right)$ & & & & \\
\hline
\end{tabular}

Note: Means in the same row with different superscripts differ significantly $(\mathrm{P}<0.05)$.

1. Wild-type E. coli W3110

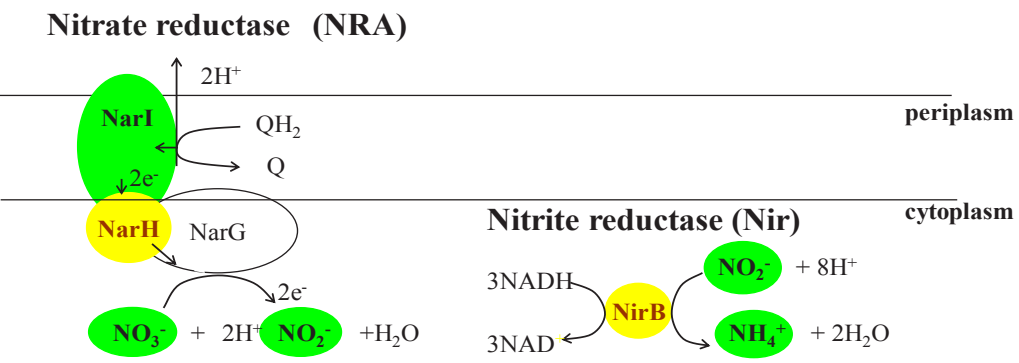

2. Construction of E. coli nir-Ptac by replacement of self-promoter (nir) in E. coli W3110 by tac promoter (Ptac) (Ajinomoto Co. Inc., Kawasaki, Japan)

E. coli $\mathrm{W} 3110$

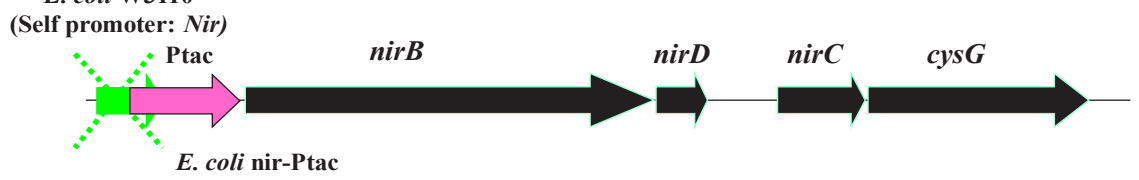

Figure 2. Wild-type E. coli W3110 and the construction of E. coli nir-Ptac

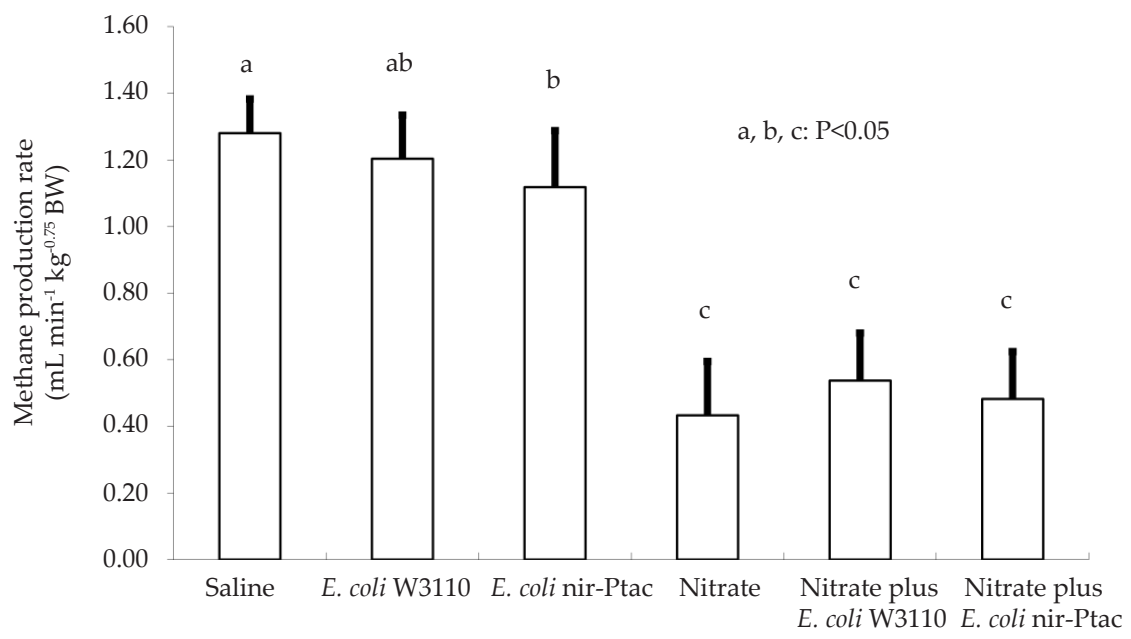

Figure 3. Effect of wild-type E. coli W3110 and the construction of E. coli nir-Ptac on rumen $\mathrm{CH}_{4}$ emission in sheep 
nutrition and livestock production as alternatives of the antibiotics due to concerns about incidences of resistant bacteria and environmental pollution by the excreted active-antibacterial substances (Mwenya et al., 2006). Nisin and saponin-containing extracts of Yucca schidigera and Quillaja saponaria have been categorized as 'generally recognized as safe (GRAS)' for human consumption by US Food and Drug Administration. Nisin produced by Lactococcus lactis subsp. lactis, antimicrobial activity against spectrum of Gram-positive bacteria is characterized bacteriocin and performed mitigating effect on ruminal methane emission (Mwenya et al., 2004a; Santoso et al., 2004b; Sar et al., 2006). Saponins are natural detergents found in variety of plants. Yucca saponins have a steroidal nucleus, whereas Quillaja saponins are triterpenoid in structure. Supplementation of saponin-rich plant extracts decreased ruminal protozoa counts and decreased methanogenesis accompanied by decrease in the ruminal acetate/ propionate $(\mathrm{A} / \mathrm{P})$ ratio in vitro and in vivo (Wallace et al., 1994; Wang et al., 2000; Takahashi et al., 2000; Santoso et al., 2004a; Mwenya et al., 2004a; Pen et al., 2006). However, Pen et al. (2007; 2008) showed in recent detailed examination that $Q$. saponaria had no effect on ruminal methanogenesis and $\mathrm{A} / \mathrm{P}$ ratio, although it suppressed protozoa number.

31-4 Galacto-oligosaccharides (GOS) are non-digestible carbohydrates in nonruminants and have a long history of research as a prebiotics food ingredient. GOS are resistant to gastrointestinal enzymes, but are selectively utilized Bifidobacteria (Sako et al., 1999). In the rumen, Bifidobacteria and Lactobacillus species utilize fructose, galactose, glucose and starch as substrates to produce lactate and acetate. Lactate is intermediate compound of a acrylate pathway during propionate production in the rumen. Meanwhile, propionate production is indirect competition with methanogens for available hydrogen. As Bifidobacteria and Lactobacillus species in the rumen can utilize GOS and produce more lactate, ruminal methanogenesis have been suppressed by GOS with or without direct-fed microbe yeasts and lactic acid bacteria (Gamo, 2001; Mwenya et al., 2004b; 2004c; 2004d: 2005; Santoso, 2004a; Sar et al., 2002; 2004b; 2004c; Takahashi et al., 2002; 2003). However, the efficacy of GOS with the probiotics on different diets and animal species remains to be elucidated.

\section{POSSIBLE CONTROL OF METHANOGENESIS BY HYDROGEN ACCEPTORS OR ALTERNATIVE MECHANISMS}

Rumen manipulation with ionophores such as monensin has been reported to abate rumen methanogenesis (Mwenya et al., 2005), However, there is an increasing interest in exploiting prebiotics and probiotics as natural feed additives to solve problems in animal nutrition and livestock production as alternatives of the antibiotics due to concerns about incidences of resistant bacteria and environmental pollution by the excreted active-antibacterial substances (Mwenya et al., 2006). Nisin and saponin-containing extracts of Yucca schidigera and Quillaja saponaria have been categorized as 'generally recognized as safe (GRAS)' for human consumption by US Food and
Drug Administration. Nisin produced by Lactococcus lactis subsp. lactis, antimicrobial activity against spectrum of Gram-positive bacteria is characterized bacteriocin and performed mitigating effect on ruminal methane emission (Mwenya et al., 2004a; Santoso et al., 2004b; Sar et al., 2006). Saponins are natural detergents found in variety of plants. The saponins contained in $Y$. schidigera have a steroidal nucleus, whereas $Q$. saponaria saponins are triterpenoid in structure.

There has been a growing interest in utilizing antimicrobial substances to selectively target rumen methanogens to reduce $\mathrm{CH}_{4}$ emissions (Nollet et al., 1998; Less et al., 2002; Asa et al., 2010). Figure 5 shows that effects of protease-resistant antimicrobial substances (PRA) produced by Lactobacillus plantarum and Leuconostoc citreum on rumen methanogenesis were examined using the in vitro continuous methane quantification system (Asa, 2010). Four different strains of lactic acid bacteria, Control: Lactococcus lactis ATCC19435 (non-antibacterial substances), Nisin-Z: Lactococcus lactis NCIMB702054, PRA-1: Lactobacillus plantarum TUA1490L, and PRA-2: Leuconostoc citreum JCM9698 were individually cultured in GYEKP medium. An $80 \mathrm{~mL}$ aliquot of each supernatant was inoculated into phosphate-buffered rumen fluid. PRA-1 remarkably decreased cumulative methane production. For PRA-2, there were no effects on $\mathrm{CH}_{4}$ and $\mathrm{CO}_{2}$ production and fermentation characteristics in mixed rumen cultures. The results suggested that PRA-1 reduced the number of methanogens or inhibited utilization of hydrogen in rumen fermentation.

Figure 6 shows DGGE band patterns of archaea and eubacteria. All fluorescence brightness of methanogens

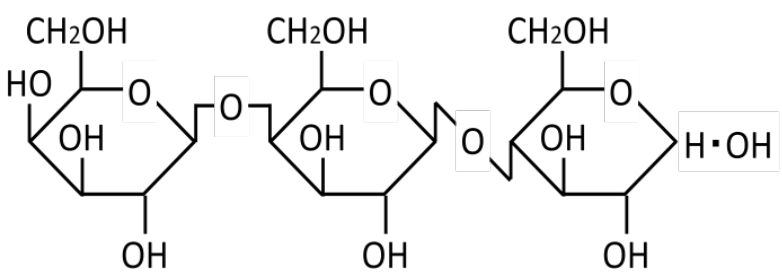

Figure 4. Chemical structure of $\beta 1-4$ galacto-oligosaccharides

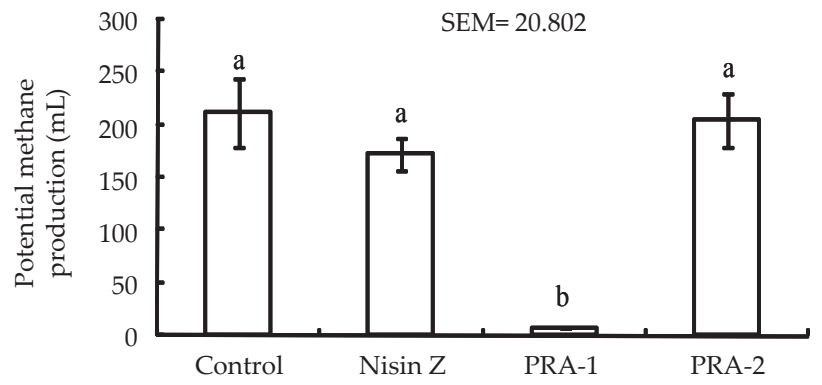

Figure 5. Effect of PRA on potential methane production.Control: Lactococcus lactis ATCC19435 (non-antibacterial substances), Nisin-A: Lactococcus lactis NCIMB702054, PRA-1: Lactobacillus plantarum TUA1490L), and PRA2: Leuconostoc citreum JCM9698. Vertical bars represent standard deviation $(n=4)$. Means with different letters differ significantly $(\mathrm{P}<0.01)$ 
bands of PRA-1 were remarkably light in color compared with control. Band No. 1 to No. 3 in archae might be Methanobrevibacter sp. which is a Gram positive bacterium or parasitic methanogens sticking on protozoan surface. PRA-1 increased the fluorescence brightness of the band of the Gram positive bacteria and declined the fluorescence brightness of the band of the Gram negative bacteria. For Gram positive bacteria, Streptococcus sp., Clostridium sp., Butyrivibrio sp. and Clostridium aminophilum were increased, whereas Prevotella sp., Prevotella ruminicola, Pseudobutyrivibrio sp, Prevotella sp, Succinivibrio dextrinosolvens and Schwartzia succinivorans in Gram negative bacteria were decreased by adding PRA-1. The supernatant of Lactobacillus plantarum TUA1490L (LP) reduced in vitro $\mathrm{CH}_{4}$ production, but the non-proteinaceous anti-microbial substance (PRA-1) was not identified, but has subsequently been shown to be hydrogen peroxide $\left(\mathrm{H}_{2} \mathrm{O}_{2}\right)$ (J. Takahashi, pers. Comm.).

The anti-microbial effect of $\mathrm{H}_{2} \mathrm{O}_{2}$ has been attributed to its strong oxidizing effect on bacterial cells and to the destruction of the molecular structure of cell proteins (Ito et al., 2003; Zalán et al., 2005). However, there is no information available on the effect of $\mathrm{H}_{2} \mathrm{O}_{2}$ on rumen fermentation. Thus, it was necessary to assess if methanogenesis was more sensitive to $\mathrm{H}_{2} \mathrm{O}_{2}$ in the LP supernatant than primary and secondary rumen fermentation processes that produce volatile fatty acids (VFA). The effect of supernatant of Lactobacillus plantarum TUA1490L on in vitro rumen $\mathrm{CH} 4$ output was investigated minutely with in vitro gas quantification system (Takasugi Seisakusho, Tokyo, Japan, Takahashi \& Kawabe, 2011) installed auto infrared $\mathrm{CH}_{4}$ (EXA IR, Yokogawa, Tokyo, Japan) and $\mathrm{CO}_{2}$ (Model RI-555, Riken Keiki, Tokyo, Japan) analyzers (O'Brien, 2013). In consequence, $\mathrm{H}_{2} \mathrm{O}_{2}$ was detected in the supernatant and $\mathrm{CH}_{4}$ output was reduced by $72 \%$. However, the supernatant has an adverse effect on total VFA concentration. Follow-on studies will examine if lower additions of chemically-synthesized $\mathrm{H}_{2} \mathrm{O}_{2}$ can reduce $\mathrm{CH}_{4}$ output without significantly reducing total VFA production.

\section{CREATION OF RENEWABLE ENERGY (BIOGAS) FROM ANAEROBIC FERMENTATION (BIOGAS PLANT) OF ANIMAL MANURES AND THE INNOVATIVE REUSE OF THE DIGESTED SLURRY TO MITIGATE $\mathrm{N}_{2} \mathrm{O}$}

The increased emissions of $\mathrm{CH}_{4}$ and $\mathrm{N}_{2} \mathrm{O}$ from decomposing unmanaged and bio-based industrial wastes along with the expansion of human activities contribute climate change as GHG. The conventional biogas system based on anaerobic fermentation of the organic wastes, however, is not a nitrogen recycling but carbon recycling one. Therefore, isometric fertilization of the digested slurry after anaerobic fermentation may not be a solution of current issue on excess nitrogen abatement, although nitrous oxide emission is almost completely suppressed during anaerobic fermentation (Figure 7).

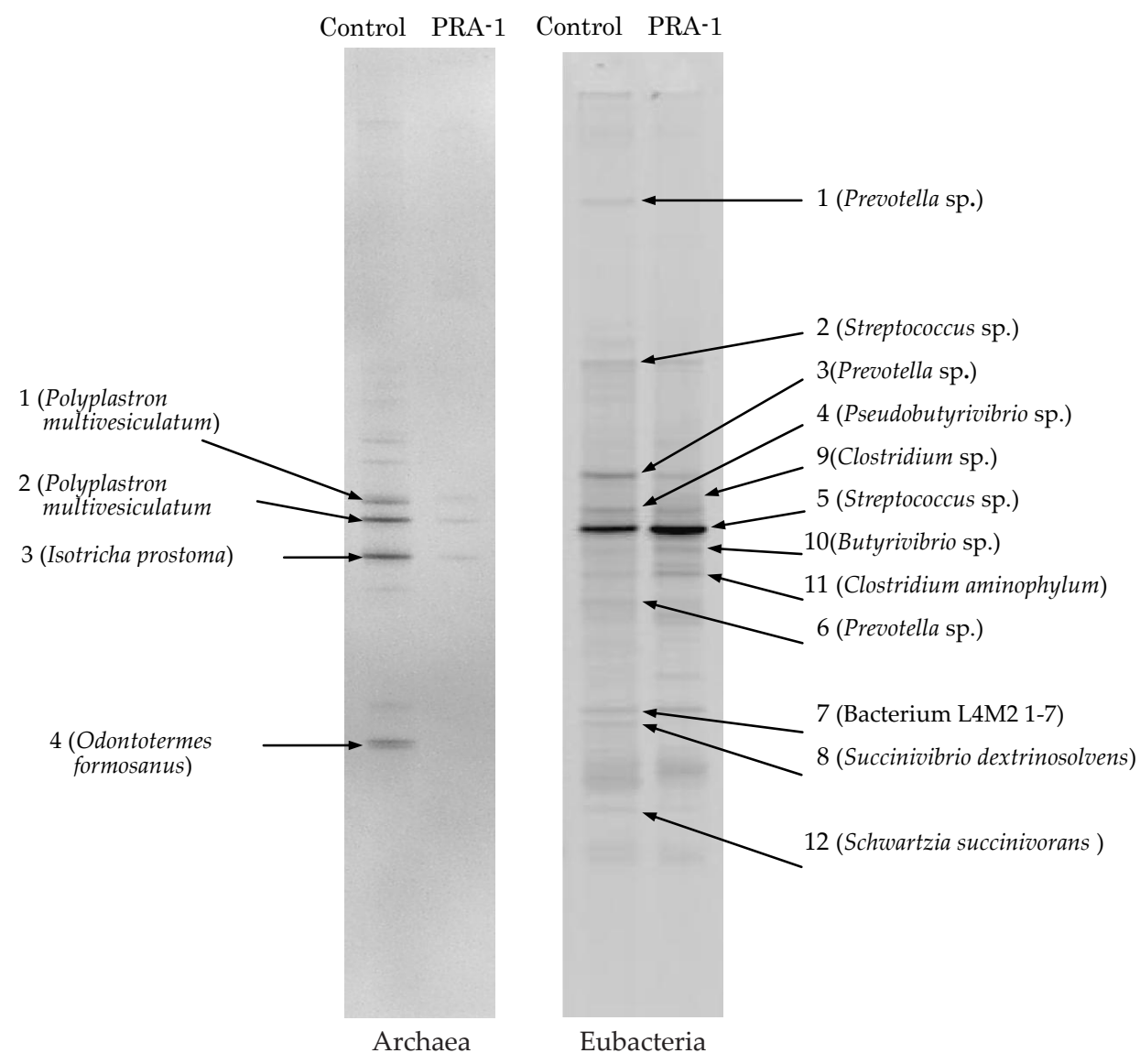

Figure 6. DGGE band patterns of rumen archaea and eubacteria 


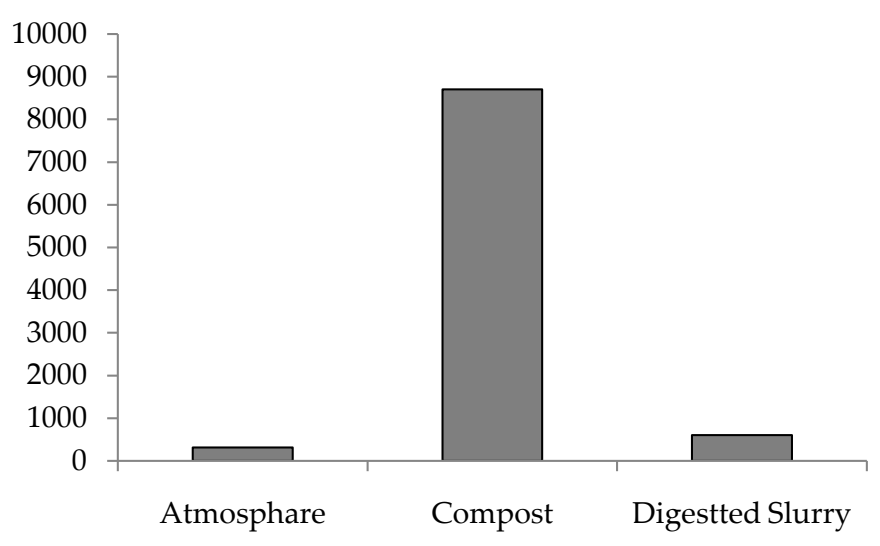

Figure 7. $\mathrm{N}_{2} \mathrm{O}$ emission from different manure treatments

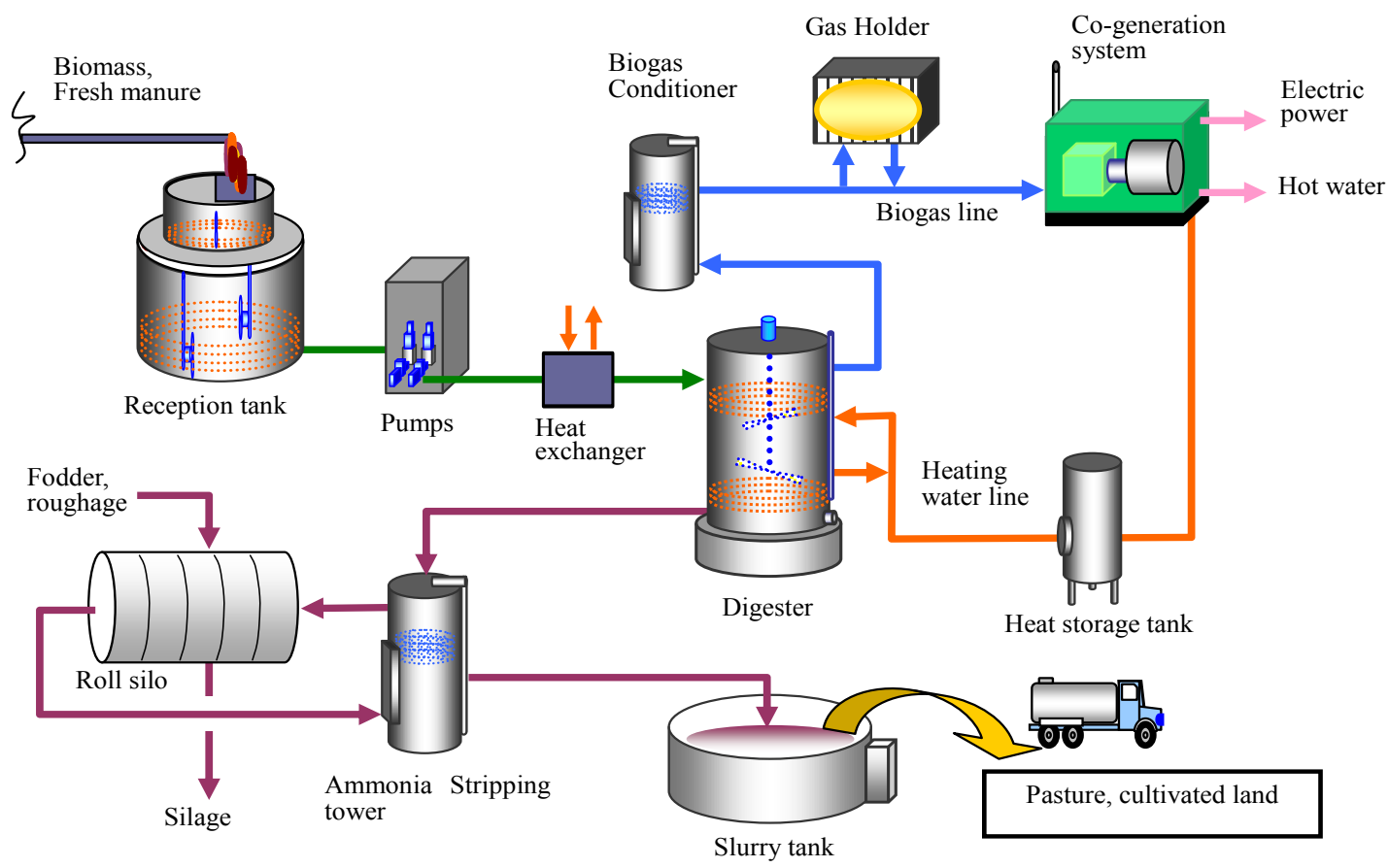

Figure 8. Advanced biogas system-high efficient wastesrecyclingandco-generation

It causes not only methane emission, but also nitrate leaching and $\mathrm{N}_{2} \mathrm{O}$ emission from soil (Takahashi, 2006). The introduction of ammonia stripping from digested slurry of themophilic biogas plant might be a solution to reduce total nitrogen content of the slurry as a liquid fertilizer containing suitable nitrogen and eventually can contribute the mitigation of $\mathrm{N}_{2} \mathrm{O}$ emission as a new concept of biogas system (Figure 8). Furthermore, the stripped ammonia can be put to practical use as a low-input and renewable nitrogen resource without energy supply from outside, because abundant amount of organic wastes exist in developing countries and the energy required for ammonia stripping can be supplied from biogas plant attached to the ammonia stripping apparatus. The following three options have been examined for future nitrogen recycling. Production of high quality feed from cellulose biomass in agricultural waste with ammonia stripping process from digested slurry of biogas plant (Takahashi, 2006; 2007). Saccharification of soft cellulose biomass to create bio-ethanol and hydrogen using ammonolysis by stripped ammonia from effluent and hydrolysis of rumen bacteria (unpublished). Ammonia fuel cell with ammonia stripping from digested slurry (Takahashi \& Uemura, 2009; FOCUS, April 14, 2009).

\section{CONCLUSION}

The amplifying competition of metabolic $\mathrm{H}_{2}$ with probiotics may be a key factor in the regulation of rumen methanogenesis. However, direct mitigating effects of prebiotics and secondary metabolites such as tannin, saponin and natural resin on methanogens and eubacteria in the rumen remain to be elucidated to secure the safety for animals, their products and environment. Thus, the mechanism for international accreditation of manipulators must be established to mitigate global $\mathrm{CH}_{4}$ emission. 
By contrast, the biogas plant produce biogas including combustible $\mathrm{CH}_{4}$ as renewable energy using unused resources like animal manures, can provide fuel, heat and electricity, and minimize the impact on the environment thus reducing the amount of pollutants discharged. Furthermore, the new advanced biogas system equipped with ammonia stripping apparatus will contribute to mitigate $\mathrm{N}_{2} \mathrm{O}$ recycling excess amount of ammonia from the digested slurry.

\section{REFERENCES}

Asa, R., A. Tanaka, A. Uehara, I. Shinzato, Y. Toride, N. Usui, K. Hirakawa, \& J. Takahashi. 2010. Effects of protease-resistant antimicrobial substances produced by lactic acid bacteria on rumen methanogenesis. Asian-Aust. J. Anim. Sci. 23:700-707.

Baker, S. K. 1999. Rumen methanogens, and inhibition of methanogenesis. Aust. J. Agric. Res. 50: 1293-1298. http://dx.doi. org/10.1071/AR99005

Belaich, J. P., M. Bruschi, \& J. L. Garcia. 1990. Microbiology and Biochemistry of Strict Anaerobes Involved in Interspecies Hydrogen Transfer. Plenum Press, New York, NY. http://dx.doi.org/10.1007/978-1-4613-0613-9

Chalupa, W. 1984. Manipulation of rumen fermentation. In: W. Haresign \& D. Cole (Ed.) Recent Advances in Animal Nutrition. Butterworths, London, England, pp.143-160.

Chen, M. \& M. J. Wolin. 1979. Effect of monensin and lasalocidsodium on the growth of methanogenic and rumen saccharolytic bacteria. Appl. Environ. Microbiol. 38: 72-77

Gamo, Y., M. Mii, X. G. Zhou, C. Sar, B. Santoso, I. Arai, K. Kimura, \& J. Takahashi. 2001. Effects of lactic acid bacteria, yeasts and galactooligosaccha-ride supplementation on in vitro rumen methane production. In: J. Takahashi \& B. A. Young (Eds.). Proceedings of the 1st International Conference on Greenhouse Gases and Animal Agriculture (GGAA), Obihiro, Japan, 7-11 Nov. 2001, Obihiro, Hokkaido, Japan. Pp 371-374.

Hopgood, M. F. \& D. J. Walker. 1967. Succinic acid production by rumen bacteria. II. Radioisotope studies on succinateproduction by Ruminococcus flavefaciens. Aust. J. Biol. Sci. 20: 183-192.

IPCC. 1996. Revised 1996. IPCC Guidelines for National Greenhouse Gas Inventories. IPCC-NGGIP.

Ito, A., Y. Sato, S. Kudo, S. Sato, H. Nakajima, \& T. Toba. 2003. The screening of hydrogen peroxide-producing lactic acid bacteria and their application to inactivating pschrotrophic food-borne pathogens. Curr. Microbiol. 47: 231-236. http://dx.doi.org/10.1007/s00284-002-3993-1

Klieve, A. V. \& R. S. Hegarty. 1999. Opportunities of biological control of ruminant methanogenesis. Aust. J. Agric. Res. 50: 1315-19. http://dx.doi.org/10.1071/AR99006

Komiyama, M., K. Umetsu, \& J. Takahashi. 2006. Biogas as a reproducible energy source:Its steam reforming for electricity generation and for farm machine fuel. In: R. C. Soliva, J. Takahashi, \& M. Kreuzer (Eds.). Greenhouse Gases and Animal Agriculture: An Update, Elsevier Science, 234-237.

Leng, R. A. 1991. Improving ruminant production and reducing methane emissions from ruminants by strategic supplementation. EPA/400/1-91/004, US Environmental Protection Agency, Washington, D C, 6-10.

Less, S. S., J. Hsu, H. C. Mantovani, \& J. B. Russell. 2002. The effect of bovine HC5, a bacteriosin from Streptcoccus bovis $\mathrm{HC} 5$, on ruminal methane production in vitro. FEMS Microbiol. Lett. 217:51-55. http://dx.doi.org/10.1111/j.15746968.2002.tb11455.x
Moss, A. R. 1993. Methane: Global Warming and Production by Animals. Cantebury. Chalcombe Publications.

Mwenya, B., C. Sar, Y. Gamo, T. Kobayashi, R. Morikawa, K. Kimura, H. Mizukoshi, \& J. Takahashi. 2004a. Effects of Yucca schidigera with or without nisin on ruminal fermentation and microbial protein synthesis in sheep fed silage- and hay- based diets. Anim. Sci. J. 75: 525 - 531. http://dx.doi.org/10.1111/j.1740-0929.2004.00223.x

Mwenya, B., X., Zhou, B. Santoso, C. Sar, Y. Gamo, T. Kobayashi, \& J. Takahashi. 2004b. Effects of probiotic-vitacogen and b1-4 galacto-oligosaccharides supplementation on methanogenesis and energy and nitrogen utilization in dairy cows. Asian-Aust. J. Anim. Sci. 17: 349-354.

Mwenya, B., B. Santoso, C. Sar, B. Pen, R. Morikawa, K. Takaura, K. Umetsu, K. Kimura, \& J. Takahashi. 2004c. Effects of yeast culture and galacto-oligosaccharides on ruminal fermentation in Holstein cows. J. Dairy Sci. 88: 1404-1412. http://dx.doi.org/10.3168/jds.S0022-0302(05)72808-3

Mwenya, B., B. Satonso, C. Sar, Y. Gamo, T. Kobayashi, I. Arai, \& J. Takahashi. 2004d. Effects of including b1-4 galacto-oligosaccharides, lactic acid bacteria or yeast culture on methanogenesis as well as energy and nitrogen metabolism in sheep. Anim. Feed. Sci. Technol. 115: 313- 326. http://dx.doi.org/10.1016/j.anifeedsci.2004.03.007

Mwenya, B. C. Sar, B. Santoso, T. Kobayashi, R. Morikawa, K. Takaura, K. Umetsu, S. Kogawa, K. Kimura, H. Mizukoshi, \& J. Takahashi. 2005. Comparing the effects of b1-4 galacto-oligosaccharides and L-cysteine to monensin on energy and nitrogen utilization in steers fed a very high concentrate diet. Anim. Feed Sci. Technol. 118: 19-30. http://dx.doi.org/10.1016/j.anifeedsci.2004.10.014

Mwenya, B. C. Sar, B. Pen, R. Morikawa, K. Takaura, S. Kogawa, K. Kimura, K. Umetsu, \& J. Takahashi. 2006. Effects of feed additives on ruminal methanogenesis and anaerobic fermentation of manure in cows and steers. In: C. Soliva, J. Takahashi, \& M. Kreutzer (Eds). Greenhouse Gases on Animal Agriculture update. International Congress Series. Elsevier, Amsterdam. 1293: 209-212.

Nollet, L., L. Mbanzamihigo, D. Demeyer, \& W. Verstraete. 1988. Effect of the addition of Peptostreptococcus ATCC 35244 on reductive acetogenesis in the rumeminal ecosystem after inhibition of methanogenesis by cell-free supernatant of Lactobatillus plantarum 80. Anim. Feed Sci. Technol. 71: 700-7007.

O'Brien, M., T. Hashimoto, A. Senda, T. Nishida, \& J. Takahashi. 2013. The impact of Lactobacillus plantarum TUA1490L supernatant on in vitro rumen methanogenesis and fermentation. Anaerobe 22:137-140. http://dx.doi. org/10.1016/j.anaerobe.2013.06.003

Pen, B., C. Sar, B. Mwenya, K. Kuwaki, R. Morikawa, \& J. Takahashi. 2006. Effects of Yucca schidigera and Quillaja saponaria extracts on in vitro ruminal fermentation and methane emission. Anim. Feed Sci. Technol. 129: 175-186. http://dx.doi.org/10.1016/j.anifeedsci.2006.01.002

Pen, B., K. Takaura, S. Yamaguchi, R. Asa, \& J. Takahashi. 2007. Effects of Yucca schidigera and Quillaja saponaria with or without $\beta$ 1-4 galacto-oligosaccharides on ruminal fermentation, methane production and nitrogen utilization in sheep. Anim. Feed Sci. Technol. 138: 75-88. http://dx.doi. org/10.1016/j.anifeedsci.2006.11.018

Pen, B., C. Sar, B. Mwenya, K. Kuwaki, \& J. Takahashi. 2008. Effects of Quillaja saponaria extract alone or in combination with Yucca schidigera extract on ruminal fermentation and methanogenesis in vitro. Anim. Sci. J. 79: 193-199. http://dx.doi.org/10.1111/j.1740-0929.2008.00517.x

Sako, T., K. Matsumoto, \& R. Tanaka. 1999. Recent progress on research and application of non-digestible galacto-oligosaccharides. Int. Dairy J. 9: 69-80. http://dx.doi.org/10.1016/ S0958-6946(99)00046-1 
Santoso, B., B. Mwenya, C. Sar, Y. Gamo, T. Kobayashi, R. Morikawa, K. Kimura, H. Mizukoshi, \& J. Takahashi. 2004a. Effects of supplementing galacto-oligosaccharides, Yucca schidigera or nisin on rumen methanogenesis, nitrogen and energy metabolism in sheep. Livest. Prod. Sci. 91: 209-217. http://dx.doi.org/10.1016/j.livprodsci.2004.08.004

Santoso, B., B. Mwenya, C. Sar, Y. Gamo, T. Kobayashi, R. Morikawa, \& J. Takahashi. 2004b. Effect of Yucca schidigera with or without nisis on ruminal fermentation and microbial protein synthesis in sheep fed silage- and hay-based diets. Anim. Sci. J. 75:525-531. http://dx.doi. org/10.1111/j.1740-0929.2004.00223.x

Sar, C., B. Santoso, X.G. Zhou, Y. Gamo, A. Koyama, T. Kobayashi, S. Shiozaki, \& J. Takahashi. 2002. Effects of $§ 1-4$ galacto-oligosaccharide (GOS) and Candida kefyr on nitrate-induced methaemoglobinemia and methane emission in sheep. In: J. Takahashi \& B. A. Young (Eds). Greenhouse Gases on Animal Agriculture. Elsevier, Amsterdam.

Sar, C., B. Santoso, B. Mwenya, R. Morikawa, N. Isogai, Y. Asakura, Y. Toride, \& J. Takahashi. 2004a. Effect of Escherichia coli W3110 or Escherichia coli nir-Ptac on in vitro ruminal methanogenesis and nitrate/nitrite reduction. Proceeding of 11th Asian-Australasian Association of Animal Production Societies (AAAP) Congress, 5-9th September 2004, Kuala Lumpur, Malaysia. Pp 316-318.

Sar, C., B. Santoso, Y. Gamo, T. Kobayashi, S. Shiozaki, K. Kimura, H. Mizukoshi, I. Arai, \& J. Takahashi. 2004b. Effects of combination of nitrate with B1-4 galacto-oligosaccharides and yeast (Candida kefyr) on methane emission from sheep. Asian-Aust. J. Anim. Sci. 17: 73-79.

Sar, C., B. Santoso, B. Mwenya, Y. Gamo, T. Kobayashi, R. Morikawa, K. Kimura, H. Mizukoshi, \& J. Takahashi. 2004c. Manipulation of rumen methanogenesis by the combination of nitrate with $181-4$ galacto-oligosaccharides or nisin in sheep. Anim. Feed Sci. Technol. 115: 129-142. http://dx.doi.org/10.1016/j.anifeedsci.2004.01.006

Sar, C., B. Mwenya, B. Pen, K. Takaura, R. Morikawa, A. Tsujimoto, K. Kuwaki, N. Isogai, I. Shinzato, Y. Asakura, Y. Toride, \& J. Takahashi. 2005a. Effect of rumianl administration of Escherichia coli wild type or a genetically modified strain with enhanced high nitrite reductase activity on methane emission and nitrate toxicity in nitrate-infused sheep. Br. J. Nutr. 94: 691-697. http://dx.doi.org/10.1079/ BJN20051517

Sar, C., B. Mwenya, B. Santoso, K. Takaura, R. Morikawa, N. Isogai, Y. Asakura, Y., Toride, \& J. Takahashi. 2005b. The effect of Escherichia coli W3110 on ruminal methanogenesis and nitrate/nitrite reduction in vitro. Anim. Feed Sci. Technol. 118: 295-306. http://dx.doi.org/10.1016/ j.anifeedsci.2004.10.004

Sar, C., B. Mwenya, B. Santoso, K. Takaura, R. Morikawa, N. Isogai, Y. Asakura, Y. Toride, \& J. Takahashi. 2005c. Effect of Escherichia coli wild type or its derivative with high nitrite reductase activity on ruminal methanogenesis and nitrate/nitrite reduction in vitro. J. Anim. Sci. 83:644-652.

Sar, C., B. Mwenya, B. Pen, R. Morikawa, K. Takaura, T. Kobayashi, \& J. Takahashi. 2006. Effect of nisin on ruminal methane production and nitrate/nitrite reduction in vitro. Aust. J. Agric. Res. 56: 803-810. http://dx.doi.org/10.1071/ AR04294

Takahashi, J., N. Johchi, \& H. Fujita. 1989. Inhibitory effects if sulphur compounds, copper and tungsten on nitrate reduction by mixed rumen micro-organisms. Br. J. Nutr. 61:742-748. http://dx.doi.org/10.1079/BJN19890159

Takahashi, J. \& B. A. Young. 1991. Prophylacticeffect of L-cysteine on nitrate-induced alteration in respiratory exchange and metabolic rate in sheep. Anim. Feed Sci. Technol. 35:105-113. http://dx.doi.org/10.1016/0377-8401(91)90103Y
Takahashi, J. \& B. A. Young. 1992. The modulation of nitrateenhanced hypothermia by sulphur compounds in cold-exposed sheep. Anim. Feed Sci. Technol. 39:347-355. http:// dx.doi.org/10.1016/0377-8401(92)90053-9

Takahashi, J, A. S. Chaudhry, R. G. Beneke, Suhubdy, \& B. A. Young. 1997. Modification of methane emission in sheep by cysteine and a microbial preparation. Sci. Total Environ., 204: 117-123. http://dx.doi.org/10.1016/S00489697(97)00162-9

Takahashi, J., M. Ikeda, S. Matsuoka, \& H. Fujita. 1998. Prophylactic effect of L-cysteine to acute and subclinical nitrate toxicity in sheep. Anim. Feed Sci. Technol. 74:273-280. http://dx.doi.org/10.1016/S0377-8401(98)00176-X

Takahashi, J., Y. Miyagawa, Y. Kojima, \& K. Umetsu. 2000. Effects of Yucca schidigera extract, probiotics, monensin and L-cysteine on rumen methanogenesis. Asian-Aust. J. Anim. Sci. 13:499-501.

Takahashi, J. 2001. Nutritional manipulation of methanogenesis in ruminants. Asian-Aust. J. Anim. Sci. 14:131-135.

Takahashi, J., C. Sar, Y. Gamo, K. Kimura, H. Mizukoshi, \& I. Arai. 2002. Suppression of rumen methanogenesis by alternative reductions. Proceeding of 10th International Congress, 23-27th September, 2002, New Delhi, India. p55.

Takahashi, J., Y. Gamo, B. Mwenya, B.Santoso, C. Sar, H. Umetsu, H. Mizukoshi, K. Kimura, \& O. Hamamoto. 2003. Control and energetic recycling of methane emitted from ruminants. In: W. B. Souffrant \& C. C. Metges (Eds.) Proceeding of Progress in research on energy and protein metabolism. EAAP publication, No. 109, 13-18th September 2003, Rostock-Warnemünde, Germany. pp371-374.

Takahashi, J., B. Mwenya, B. Santoso, C. Sar, K. Umetsu, T. Kishimoto, K.Nishizaki, K. Kimura, \& O. Hamamoto. 2004. Mitigation of methane emission and energy recyclying in animal agricultural system. Proceeding of 2004 International Symposium on Recent Advances in Animal Nutrition, 7th September 2004, Kuala Lumpur, Malaysia. Pp. 97-193.

Takahashi, J. 2006. Sustainable manure management in the nitrogen recycling system FLRC/NZFMRA Conference on Implementing Sustainable Nutrient Management Strategies in Agriculture, Massey University, Palmerston North, New Zealand.

Takahashi, J. 2007. Feed production from unused resources applied ammonia stripping from digested slurry of biogas plant. J. Agric. Food Technol. 3:3-5.

Takahashi, J. \& M. Uemura. 2009. Ammonia fuel cell modulated ammonia stripping from animal agricultural biomass. J. Fuel Cell Technol. 8: 93-96.

Takahashi, J. 2009. Perspective on GHG control and agricultural biomass for sustainable animal agriculture. Proceedings of International workshop on sustainable green livestock agriculture confronting climate change in APEC member economies. RDA, Korea. pp1-265.

Takahashi, J. \& H. Kawabe. 2011. A measuring method and measuring device of gas production. Japan Patent Number 474826.

Umetsu, K., Y. Kimura, \& J. Takahashi. 2005. Methane emission from stored dairy manure slurry and slurry after digestion by methane digester. Anim. Sci J. 76: 73-79. http://dx.doi. org/10.1111/j.1740-0929.2005.00240.x

Umetsu, K., S. Yasmazaki, \& J. Takahashi. 2006. Anaerobic codigestion of dairy manure and sugar beets. In: R. C. Soliva, J. Takahashi, \& M. Kreuzer (Eds.). Greenhouse Gases and Animal Agriculture: An Update, Elsevier Science, 307-310.

Van Nevel, C. J. \& D. I. Demeyer. 1996. Control of rumen methanogenesis. Environ. Monit. Assess. 42:73-97. http://dx.doi. org/10.1007/BF00394043

Walles, R. J., L. Arthaud, \& C. J. Newbold. 1994. Influence of Yucca schidigera extract in ruminal ammonia concentra- 
tions and ruminal microorganisms. Appl. Environ. Microbiol. 60: 1762-1767.

Wang, Y., T. A. McAllister, L. J. Yanke, Z. J. Xu, P. R. Cheeke, \& K. J. Cheng. 2000. In vitro effects of steroidal saponins from Yucca schidigera extract on rumen microbial protein sysnthesis and ruminal fermentation. J. Sci. Food Agric. 80:2114-2122. http://dx.doi.org/10.1002/10970010(200011)80:14<2114::AID-JSFA755>3.0.CO;2-0

Wolin, M. J. 1975. Interactions between the bacterial species of the rumen. In: I. M. McDonald \& A. C. I. Warner (Ed.). Di- gestion and Metabolism in the Ruminant. Univ. New England Publ. Unit, Sydney, Australia. pp.135-148.

Wolin, M. J. \& T. L. Miller. 1988. Microbe-microbe interactions. In: The rumen microbial ecosystem. Elsevier Applied Science, London, UK, pp. 343-359.

Zalán, Z., E. Németh, A. Baráth, \& Ā. Halász. 2005. Influence of growth medium on hydrogen peroxide and bacteriocin production of Lactobacillus strain. Food Technol. Biotechnol. 43: 219-225. 